\title{
Foraging segregation of two congeneric diving seabird species breeding on St. George Island, Bering Sea
}

\author{
Nobuo Kokubun ${ }^{1,2}$, Takashi Yamamoto ${ }^{1,3, a}$, Nobuhiko Sato ${ }^{2}$, Yutaka Watanuki ${ }^{3}$, Alexis Will ${ }^{4}$, Alexander S. Kitaysky ${ }^{4}$, \\ and Akinori Takahashi ${ }^{1,2}$ \\ ${ }^{1}$ National Institute of Polar Research 10-3 Midori-cho, Tachikawa, Tokyo 190-8518, Japan \\ ${ }^{2}$ Department of Polar Science, School of Multidisciplinary Sciences, SOKENDAI (the Graduate University for Advanced \\ Studies), 10-3 Midori-cho, Tachikawa, Tokyo 190-8518, Japan \\ ${ }^{3}$ Graduate School of Fisheries Sciences, Hokkaido University, 3-1-1 Minato-cho, Hakodate, Hokkaido 040-0821, Japan \\ ${ }^{4}$ Institute of Arctic Biology, Department of Biology and Wildlife, University of Alaska Fairbanks, Irving 311, \\ Alaska 99503, USA \\ ${ }^{a}$ present address: Graduate School of Environmental Studies, Nagoya University, Furo-cho, Chikusa-ku, Nagoya, \\ Aichi 464-8601, Japan \\ Correspondence to: Nobuo Kokubun (kokubun@nipr.ac.jp)
}

Received: 30 September 2015 - Published in Biogeosciences Discuss.: 11 November 2015

Revised: 15 March 2016 - Accepted: 12 April 2016 - Published: 29 April 2016

\begin{abstract}
Subarctic environmental changes are expected to affect the foraging ecology of marine top predators, but the response to such changes may vary among species if they use food resources differently. We examined the characteristics of foraging behavior of two sympatric congeneric diving seabird: common (Uria aalge: hereafter COMUs) and thick-billed (U. lomvia: hereafter TBMUs) murres breeding on St. George Island, located in the seasonal sea-ice region of the Bering Sea. We investigated their foraging trip and flight durations, diel patterns of dive depth, and underwater wing strokes, along with wing morphology and blood stable isotope signatures and stress hormones. Accelerationtemperature-depth loggers were attached to chick-guarding birds, and data were obtained from 7 COMUs and 12 TBMUs. Both species showed similar mean trip duration $(13.2 \mathrm{~h}$ for COMUs and $10.5 \mathrm{~h}$ for TBMUs) and similar diurnal patterns of diving (frequent dives to various depths in the daytime and less frequent dives to shallow depths in the nighttime). During the daytime, the dive depths of COMUs had two peaks in shallow $(18.1 \mathrm{~m})$ and deep $(74.2 \mathrm{~m})$ depths, while those of TBMUs were $20.2 \mathrm{~m}$ and $59.7 \mathrm{~m}$. COMUs showed more frequent wing strokes during the bottom phase of dives $\left(1.90 \mathrm{~s}^{-1}\right)$ than TBMUs $\left(1.66 \mathrm{~s}^{-1}\right)$. Fish occurred more frequently in the bill loads of COMUs $(85 \%)$ than those of TBMUs (56\%). The $\delta^{15} \mathrm{~N}$ value of blood was signif-
\end{abstract}

icantly higher in COMUs (14.5\%o) than in TBMUs (13.1\%o). The relatively small wing area $\left(0.053 \mathrm{~m}^{2}\right)$ of COMUs compared to TBMUs $\left(0.067 \mathrm{~m}^{2}\right)$ may facilitate their increased agility while foraging and allow them to capture more mobile prey such as larger fishes that inhabit deeper depths. These differences in food resource use may lead to the differential responses of the two murre species to marine environmental changes in the Bering Sea.

\section{Introduction}

The southeastern Bering Sea has one of the most productive continental shelf areas in the world's ocean, and hosts large colonies of seabirds (Sowls et al., 1978; Hunt Jr. et al., 1981b; Dragoo et al., 2015). During recent decades, the area has experienced a series of warm and cold regimes which result in contrasting responses of the plankton and nekton communities (Coyle et al., 2011; Hunt Jr. et al., 2011) and their predators (Barger and Kitaysky, 2012). Common murres (Uria aalge: hereafter COMUs) and thick-billed murres (U. lomvia: hereafter TBMUs) are abundant and closely related diving seabirds and often breed sympatrically in subarctic regions (Gaston and Jones, 1998). A range-wide comparison of COMU and TBMU population trends demonstrated 
that they have different favorable oceanographic temperature regimes for population growth reflecting importance of bottom-up effects of climate variability on their populations (Irons et al., 2008). However, how these two species respond to local variation in the environment, where their ranges overlap, is still not well understood (but see Barger et al., 2016, and references therein). Comparisons of foraging characteristics would provide insight into the respective ecological niche of these diving seabirds. A more narrow niche would be indicative of a species with specialist strategy which is predicted to show more sensitive responses to environmental changes than a species characterized as a generalist (Clavel et al., 2011; Gallagher et al., 2015).

Ecological segregation is a common mechanism that enables closely related species to coexist sympatrically (Pianka, 1981). In diving seabirds, segregation in foraging behavior has been found in horizontal, vertical and temporal dimensions (Kokubun et al., 2010a; Masello et al., 2010; Navarro et al., 2013), or in the use of prey species (Croxall et al., 1997; Hunt Jr. et al., 1981a). Both intrinsic and extrinsic factors affect the patterns of segregation. Intrinsic factors include physiology, morphology or energy requirement in relation to breeding stages, and can influence diving depth (Mori and Boyd, 2004), flight distance (Thaxter et al., 2010) or foraging habitat use (Linnebjerg et al., 2013; Barger et al., 2016). Extrinsic factors include oceanographic conditions and prey availability, and may affect the degree of interspecific competition for food resources (Lynnes et al., 2002; Barger and Kitaysky, 2012). In addition, microhabitats for nesting are often segregated (Squibb and Hunt Jr., 1983; Linnebjerg et al., 2015), which may affect allocation of time to the nest attendance vs. foraging. Potential effects of climate or human-induced environmental changes may manifest differently among species with different foraging characteristics (Kitaysky and Golubova, 2000; Trivelpiece et al., 2011). Therefore, it is important to understand the mechanisms of foraging segregation and underlying processes in marine predators.

Foraging segregation between COMUs and TBMUs has been studied mostly by the observation of chick diet. Several studies have pointed out that COMUs use fish almost exclusively, whereas TBMUs use a variety of prey (Hunt Jr. et al., 1981a; Barrett et al., 1997; Bryant et al., 1998; Barger et al., 2016). Whether/how their foraging behavior contributes to these prey differences is, however, not well known. A few studies have revealed inter- or intraspecific differences in the foraging behavior of COMUs and TBMUs from the aspects of morphology (Paredes et al., 2015) and breeding ecology (Barger et al., 2016). Paredes et al. (2015) showed that, within TBMU colonies, smaller individuals tended to fly longer distances and dive shallower, whereas the opposite pattern was observed in larger individuals, likely reflecting their body mass and wing loading. TBMUs have also shown intersexual differences in the diel patterns of diving behavior (Jones et al., 2002; Paredes et al., 2008); however, the presence of such habitat partitioning appears to vary by geographical region (Elliott et al., 2010). Between COMUs and TBMUs the overlap in horizontal and vertical foraging habitats and/or in prey species is greater during incubation than chick rearing, possibly to enhance resource partitioning between the species during the energy-demanding chickrearing period (Barger et al., 2016). In this context, a finescale study of murre diving and flight behavior combined with dietary and morphological analyses is needed to better understanding the differences in the ecological niches of these closely related species. We anticipate that fine-scale studies on foraging segregation between COMUs and TBMUs will provide insight into whether/how their responses to environmental change in the Bering Sea ecosystem may differ.

Here we investigated the differences in the foraging behavior between COMUs and TBMUs with depth-temperatureacceleration data loggers. Stable isotope analyses, observation of prey delivered to chicks, and stress hormone analyses were used to examine interspecific differences in diet and consequent nutritional stress. Based on results of previous studies, we predicted that COMUs would consume highertrophic- level prey and show more specialized foraging behavior on fish prey compared to TBMUs, which might be also associated with interspecific differences in wing morphology. We combine detailed foraging behavior, diet, and morphology to discuss how interspecific differences in the foraging behavior may affect the responses of two murre species to environmental change in the southeastern Bering Sea.

\section{Materials and methods}

\subsection{Study site}

We conducted fieldwork on St. George Island, southeastern Bering Sea, home to one of the largest murre colonies in the world (Sowls et al., 1978: 190000 COMUs and 1500000 TBMUs). Birds were captured at High Bluffs $\left(56^{\circ} 36^{\prime} \mathrm{N}, 169^{\circ} 39^{\prime} \mathrm{W}\right)$ on the northern side of the island. At our study colony, where avian predators are nearly absent, COMUs and TBMUs form mixed colonies on narrow open ledges and adults spent most of their non-foraging time at the nest brooding the chick. Instruments (see below) were deployed on chick-rearing birds from 30 July to 13 August 2014. During the study period, sunrise and sunset ranged between 07:17 and 07:44 LT and 23:33 and 23:02 LT. The start and end of nautical twilight (when the sun is less than $12^{\circ}$ below the horizon) ranged between 05:07 and 05:57 LT and 01:45 and 0:52 LT. We defined the time between sunrise and sunset as "daytime", and the time between sunset and the next sunrise as "nighttime", which includes dusk (sunset to end of nautical twilight), dark night (end of nautical twilight 
to start of next nautical twilight) and dawn (start of nautical twilight to sunrise).

\subsection{Deployment of data loggers}

We used depth-temperature-acceleration data loggers to record behavioral and environmental data during the foraging trips of adult birds. The loggers (ORI-380 D3GT: housed in a cylindrical container, $12 \mathrm{~mm}$ diameter, $45 \mathrm{~mm}$ length, mass $10 \mathrm{~g}$, Little Leonardo, Tokyo, Japan) were deployed on 13 COMUs and 15 TBMUs. The weight of the logger corresponds to $1.1 \pm 0.1 \%$ and $1.0 \pm 0.1 \%$ of body mass for $\mathrm{CO}$ MUs and TBMUs, respectively. We captured chick-rearing birds with a $5 \mathrm{~m}$ noose pole, weighed them to the nearest $5 \mathrm{~g}$ using a Pesola ${ }^{\circledR}$ balance, and then attached a logger alongside their keel with strips of Tesa ${ }^{\circledR}$ tape and cyanoacrylate glue (Loctite ${ }^{\circledR} 401$ ) to secure the end of the tape. Handling time for each bird was less than $9 \mathrm{~min}$. The loggers were set to record tri-axial acceleration (heave, surge and sway) at a rate of $20 \mathrm{~Hz}$ (every $0.05 \mathrm{~s}$ ), as well as depth (at a resolution of $0.1 \mathrm{~m}$ ) and temperature (at a resolution of $0.1^{\circ} \mathrm{C}$ ) every second.

The birds were recaptured between 1 and 6 days after deployment. The loggers were removed and the data were downloaded to a laptop computer. Upon logger retrieval, blood samples were taken for stable isotope and stress hormone analyses, and body size (body mass and wing area) was measured. The wing area of each bird was analyzed following Pennycuick (2008). We put the bird's right wing extended on a white flat board with a black colored $5 \mathrm{~cm} \times 5 \mathrm{~cm}$ square as reference, and took pictures of the wing from above. The wings were then traced in the digital picture and the pixels of the wing trace were counted using IGOR Pro (WaveMetrics Inc., Lake Oswego, OR, USA). The pixel number was converted to area $\left(\mathrm{m}^{2}\right)$ using the reference square with known area, and the total wing area was calculated by doubling the area for one wing including "root chord" (Pennycuick, 2008). Wing loading $\left(\mathrm{N} \mathrm{m}^{-2}\right)$ was calculated from body mass $(\mathrm{kg}) \times g$ (gravity acceleration: $\left.9.8 \mathrm{~m} \mathrm{~s}^{-2}\right)$ divided by wing area $\left(\mathrm{m}^{2}\right)$.

\subsection{Foraging trip and dive parameters}

During the chick-rearing period, parent murres alternate foraging at sea with brooding their chicks at the colony. We defined the duration of foraging trips (to the nearest second) as the time between departure and return to the colony. This transition was clearly marked by a rapid change in bird's body angle associated with a shift in temperature (Takahashi et al., 2008). We classified the behavior of the birds during foraging trips into diving, flight, or sitting on the water, using acceleration, depth, and temperature (Watanuki et al., 2006). The timing and duration of flight events was determined from the heaving acceleration. Foraging trips consisted of several series of dives separated by flight events
(Falk et al., 2000). Because the birds move among the foraging locations by flying, we defined the series of dives as "dive bouts" (Takahashi et al., 2008). We also estimated the potential maximum distance from the colony by calculating total flight duration during foraging trips. We used a regression between time spent in flight (h) and maximum distance from the colony $(\mathrm{km})$ during foraging trips, obtained from GPS-tracked TBMUs with time-depth recorders attached to their leg ( $n=17$ foraging trips; maximum distance from the colony $(\mathrm{km})=27.284$ (regression coefficient) $\times$ total flight duration $\left.(\mathrm{h}) ; R^{2}=0.787\right)$. The GPS-tracked birds did not carry accelerometers, the GPS data were collected concurrently to this study, and the detailed results are reported in Yamamoto et al. (2016).

For each dive we determined dive depth, dive duration, bottom time (the time between the start and end of the period when birds showed no change in the diving depth), and descent and ascent time (the time between the start of the dive and the start of the bottom phase, and the time between the end of the bottom phase and the end of the dive, respectively). A dive was considered to occur when dive depth exceeded $0.5 \mathrm{~m}$ (Watanuki et al., 2001; Takahashi et al., 2008). We calculated the number of wing strokes per unit time during the descent, bottom and ascent phases using the heaving (dorsoventral) acceleration, as an index of their underwater activity (Watanuki et al., 2003; Watanuki et al., 2006). We applied a high-pass filter $1 \mathrm{~Hz}$ to heaving acceleration such that active body movements induced by wing strokes were highlighted. Peaks in the filtered acceleration exceeding a threshold amplitude $\left(0.2 \times 9.8 \mathrm{~ms}^{-2}\right)$ were counted within a $1.0 \mathrm{~s}$ time window and summed during diving descent, bottom and ascent phases of each dive, and then divided by descent, bottom and ascent duration to calculate the wing stroke frequency in each phase. The analyses on wing strokes were made with the analysis software IGOR Pro version 6.0 (WaveMetrics Inc., Lake Oswego, OR, USA).

\subsection{Environmental parameters}

We calculated four parameters from temperature data obtained from bird-borne data loggers to characterize the thermal environment of murres' foraging locations: sea surface temperature (SST), thermocline depth, thermocline intensity and water temperature at depth $>40 \mathrm{~m}$ (Kokubun et al., $2010 \mathrm{~b})$. These parameters are known to vary spatially in the southeastern Bering Sea continental shelf (Coachman, 1986). In the vicinity of the Pribilof Islands, the areas close to the islands are expected to have lower sea surface temperature, higher temperature at depth and less intense or no thermoclines due to tidal mixing, whereas areas far from the islands are expected to show the reverse pattern: higher SST, lower temperature at depth and a more intense thermocline due to heating of the sea surface (Kinder et al., 1983; Takahashi et al., 2008). Vertical temperature profiles were determined for each dive bout, using the temperature data from the deepest 
dive of the bouts (only dives $>20 \mathrm{~m}$ were used). Because the temperature sensor had a slow response time, we corrected the temperature data for the response time following Daunt et al. (2003) and Takahashi et al. (2008). We defined thermocline depth as the depth where $\mathrm{d} T / \mathrm{d} D(T$ : temperature; $D$ : depth) was the maximum and $>0.25^{\circ} \mathrm{C}$ (Takahashi et al., 2008). We defined thermocline intensity as the difference between averaged temperatures above and below the thermocline (Kokubun et al., 2010b). The averaged water temperature below $40 \mathrm{~m}$ was assumed as water temperature at depth because the thermocline depth was shallower than $40 \mathrm{~m}$ for most dives in the study area (Kokubun et al., 2010b).

\subsection{Diet}

Chick diet was recorded from direct observation of adult birds (both with and without data loggers) carrying prey items to their nest. Prey items were visually identified to their lowest taxonomic level possible during observation or later from photographs.

We collected blood samples ( $n=14$ COMUs and 18 TBMUs, including 7 COMUs and 7 TBMUs with successful recordings of acceleration-temperature-depth data) upon retrieval of data loggers to analyze carbon and nitrogen stable isotope ratios to investigate interspecific differences in trophic levels between COMUs and TBMUs (Hobson et al., 2002). We followed Barger and Kitaysky (2012) for the sampling and analyses procedures. Blood samples were collected using heparinized syringes, transferred to $1.5 \mathrm{~mL}$ microtubes, and stored cool until centrifugation (usually no more than $8 \mathrm{~h}$ after collection). Whole blood samples were centrifuged for $5 \mathrm{~min}$ to separate plasma and red blood cells. The red blood cells were stored frozen until stable isotope analysis in the laboratory for ${ }^{13} \mathrm{C}$ and ${ }^{15} \mathrm{~N}$. A small portion of freezedried samples $(0.100-0.400 \mathrm{mg})$ was placed in a tin capsule, sealed and deposited in an EA autosampler. The stable isotope data was obtained using continuous-flow isotope ratio mass spectrometry (CFIRMS). The instrumentation used was a Delta+XP interfaced with a Costech ESC 4010 elemental analyzer. Stable isotope ratios are reported in $\delta$ (Delta) notation as parts per thousand $(\% o$ ) deviation from the international standards $\delta^{13} \mathrm{C}_{\mathrm{PDB}}$ and $\delta^{15} \mathrm{~N}_{\text {air }}$ according to $\delta X=$ $\left[\left(R_{\text {sample }} / R_{\text {standard }}\right)-1\right] \times 1000$, where $X$ is ${ }^{13} \mathrm{C}$ or ${ }^{15} \mathrm{~N}$, $R_{\text {sample }}$ and $R_{\text {standard }}$ are the corresponding ratio ${ }^{13} \mathrm{C} /{ }^{12} \mathrm{C}$ or ${ }^{14} \mathrm{~N} /{ }^{15} \mathrm{~N}$ of samples and international standards. Replicate measurement of an internal laboratory standard (Peptone) indicated measurement errors to be $\pm 0.16 \%$ o for $\mathrm{N}$ and $\pm 0.13 \%$ o for C. Samples were analyzed at the University of Alaska Fairbanks Stable Isotope Facility.

A Bayesian mixing model approach was used to infer murre diet compositions based on the stable isotope signatures of bird red blood cells and those of their potential prey, following Parnell et al. (2010) and Barger et al. (2016). This approach allows for simultaneous analysis of $\delta^{13} \mathrm{C}$ and $\delta^{15} \mathrm{~N}$ and quantifies the uncertainty of the contributions of multi- ple sources to the diet of the birds. The model combines the likelihoods for the observed $\delta^{13} \mathrm{C}$ and $\delta^{15} \mathrm{~N}$ data from the sources ( $N=7$ potential prey species) caught in the vicinity of the colony $(<100 \mathrm{~km})$. In this process, we had two constraints. First, we did not sample the sources in the study year, and so used source samples caught in 2009 instead (methods of SI analyses of prey previously reported in Barger and Kitaysky, 2012). Second, there were no available source samples of age-1 walleye pollock (Gadus chalcogrammus) within $100 \mathrm{~km}$ from the colony, a distance in which birds are more likely to forage (Yamamoto et al., 2016). Because both murres are known to deliver walleye pollock to their offspring (and thus may consume them as well) we used data from outside the $100 \mathrm{~km}$ range (133 to $161 \mathrm{~km}$ distant, $n=6$ source samples, located on the shelf, northwest of the study colony). The enrichment factors were set to -0.19 and $2.25 \%$ for $\delta^{13} \mathrm{C}$ and $\delta^{15} \mathrm{~N}$, respectively, following Barger et al. (2016). We recognize that prey stable isotope signatures may vary spatially (Jones et al., 2014: between on-shelf and off-shelf) and/or temporally (among years). However, we are primarily interested in comparing COMU and TBMU diets within the same season at the same breeding location, and thus use these source values as a proxy to compare the relative trophic position and obtain insights into potential interspecific differences in prey composition (e.g., Fig. 6). The enrichment factors were subtracted from the isotope values of red blood cells prior to the analysis. The analyses were conducted using the "SIAR" package (Parnell et al., 2010) in $\mathrm{R}^{\circledR}$ 3.1.1 software (R Development Core Team, 2014).

\subsection{Stress hormone and sexing}

We measured circulating levels of baseline corticosterone (CORT) in the plasma samples to infer the level of nutritional stress parents experiences as a result of foraging conditions ( $n=11$ COMUs and 22 TBMUs). All birds were sampled according to a standardized technique (Benowitz-Fredericks et al., 2008), with a blood sample was collected within $3 \mathrm{~min}$ of capture.

We used DNA extracted from red blood cells to genetically sex our study birds (see Griffiths et al., 1998). However, in some cases, we did not collect blood samples from the instrumented birds ( $n=5$ TBMUs). In these cases we employed a linear discriminant analysis (LDA: see Niizuma et al., 1999) using external traits (bill length, bill depth, headbill length, tarsus length and wing length) with known sex ( $n=53$ TBMUs), previously collected at the study colony (N. Kokubun, unpublished data). The efficiency of the discriminant function is $80 \%$. We considered that the morphologically determined sex in three TBMUs was reliable, because their posterior classification probability was larger than $80 \%$, but we could not determine sex of the other two individuals with posterior classification probability lower than $80 \%$. We used "MASS" package in $\mathrm{R}^{\circledR} 3.1 .1$ software (R Development Core Team, 2014) for LDA analysis. 


\subsection{Statistics}

Morphology (body mass, wing area and wing loading), foraging trip parameters (trip duration, total flight duration, number of dive bouts per trip and bout duration), baseline CORT and stable isotopic values were compared between the species by one-way ANOVA. The proportion of different prey types was compared between the species by a $\chi^{2}$ test. The proportion of daytime/nighttime dives or deep/shallow dives was compared between the species by use of generalized linear models (GLMs). A binomial error distribution was used for GLMs. Sea surface temperature (SST), temperature at depth $(>40 \mathrm{~m})$, thermocline depth and thermocline intensity where dive bouts occurred were compared between the species by use of generalized linear mixed models (GLMMs). Also, dive depth and number of wing strokes were compared between the species by GLMMs. In the GLMMs, species was set as a fixed factor, and bird identity was included as a random factor. In the analyses of number of wing strokes, we included the dive depth as a fixed factor, as dive depth can affect buoyancy and wing stroke frequency (Watanuki et al., 2006). In the GLMMs, a gamma error distribution was used, and the models with and without the effect of fixed factors (species) were compared using a likelihood ratio test (LRT). We compared the foraging parameters between the sexes if applicable. We used Minitab ${ }^{\circledR}$ v. 14 for one-way ANOVA and $\chi^{2}$ tests, and the "Ime4" package in $\mathrm{R}^{\circledR}$ 3.1.1 software (R Development Core Team, 2014) for GLMs and GLMMs. Data are presented as mean values \pm standard deviation (SD), with significance set at the 0.05 level.

\section{Results}

\subsection{Data recovery}

We recaptured 11 of 13 instrumented COMUs and all of 15 instrumented TBMUs. The remaining 2 COMUs were not observed after the planned timing of retrieval. Among the retrieved data loggers, 4 from COMUs and 3 from TBMUs did not record data properly due to memory malfunctions. Overall, we analyzed behavioral data from 7 COMUs (consisting of 4 males and 3 females) and 12 TBMUs (consisting of 3 males, 7 females and 2 unknown sexes). These data covered 14 and 21 foraging trips that included 64 and 79 dive bouts for COMUs and TBMUs, respectively (Table 1).

COMUs had smaller body mass (COMUs: $946 \pm 45 \mathrm{~g}$; TBMUs: $1023 \pm 64 \mathrm{~g}$; one-way ANOVA, $F_{1,17}=7.8$, $P=0.013$ ), smaller wing area (COMUs: $0.053 \pm 0.007 \mathrm{~m}^{2}$; TBMUs: $0.067 \pm 0.007 \mathrm{~m}^{2}$; one-way ANOVA, $F_{1,17}=16.4$, $P=0.001$ ), and greater wing loading than TBMUs (COMUs: $176 \pm 26 \mathrm{~N} \mathrm{~m}^{-2}$; TBMUs: $151 \pm 20 \mathrm{~N} \mathrm{~m}^{-2}$; one-way ANOVA, $F_{1,17}=5.6, P=0.031$ ). There were no significant differences in these morphological parameters between the sexes in either COMUs or TBMUs (one-way ANOVA, $P>0.05)$.

\subsection{Trip parameters}

Foraging trip duration, total flight duration and dive bout duration did not differ between COMUs and TBMUs (Table 1). There was no significant difference in trip and bout duration between the sexes in COMUs and TBMUs (oneway ANOVA, $P>0.05$ ). The total flight durations of male COMUs were longer than those of females $(2.1 \pm 0.7 \mathrm{~h}$ for males and $1.0 \pm 0.3 \mathrm{~h}$ for females; one-way ANOVA, $\left.F_{1,12}=13.7, P=0.003\right)$. There was no significant difference between the sexes in TBMU total flight duration (oneway ANOVA, $P>0.05$ ). The maximum distance from the colony during foraging trips estimated by total flight duration was $42.6 \pm 21.1 \mathrm{~km}$ (ranging 12.8-81.2 km) for COMUs and $38.1 \pm 21.9 \mathrm{~km}$ (ranging $4.4-76.4 \mathrm{~km}$ ) for TBMUs, respectively. With these small foraging ranges, both COMUs and TBMUs probably foraged on the continental shelf (bottom depth < 200 m: Yamamoto et al., 2016).

\subsection{Environmental use}

The sea surface temperature (SST), where the dive bouts occurred, did not differ between COMUs and TBMUs (Fig. 1a, b: COMUs: $11.9 \pm 0.4^{\circ} \mathrm{C}$; TBMUs: $11.8 \pm 0.7^{\circ} \mathrm{C}$; GLMM with LRT, $\left.\chi^{2}=0.01, P=0.91\right)$. The temperature at depth $(>40 \mathrm{~m})$ did not differ between COMUs and TBMUs (Fig. 1c, d: COMUs: $4.8 \pm 0.9^{\circ} \mathrm{C}$; TBMUs: $4.9 \pm 0.7^{\circ} \mathrm{C}$; GLMM with LRT, $\left.\chi^{2}=0.02, P=0.90\right)$. The thermocline depth $(19.6 \pm 2.2 \mathrm{~m}$ for COMUs and $21.1 \pm 4.3 \mathrm{~m}$ for TBMUs) and thermocline intensity $\left(5.4 \pm 1.1^{\circ} \mathrm{C}\right.$ for COMUs and $5.3 \pm 1.1^{\circ} \mathrm{C}$ for TBMUs) did not differ between the species (GLMM with LRT, $P>0.05$ ). There were no significant differences between the sexes in either the COMU or TBMU environmental use data (GLMM with LRT, $P>0.05)$.

\subsection{Dive parameters}

Both COMUs and TBMUs showed a diel diving pattern that indicated more dives with divergent depths in the daytime and fewer dives with shallow depths in the nighttime (Fig. 1). The proportion of the daytime and nighttime dives did not differ between the species $(62.0 \pm 21.5$ and $63.1 \pm 28.7 \%$ for daytime, and $38.0 \pm 21.5$ and $37.0 \pm 28.7 \%$ for nighttime for COMUs and TBMUs, respectively; GLM, $t=0.528$, $P=0.605)$. During the daytime, birds dove to both shallow $(<40 \mathrm{~m})$ and deep $(>40 \mathrm{~m})$ depths in regard to the maximum thermocline depth (Fig. 3a, b, c, d: $58.0 \pm 25.7$ and $42.4 \pm 16.4 \%$ for shallow dives, $42.0 \pm 25.7$ and $57.6 \pm 16.4 \%$ for deep dives, for COMUs and TBMUs, respectively; GLM, $t=1.952, P=0.068$ ). In the nighttime, both COMUs and TBMUs dove almost exclusively to shallow $(<40 \mathrm{~m}$ ) depths (Fig. 3g, h: $88.9 \pm 8.5$ and $86.5 \pm 8.8 \%$ 
Table 1. Trip parameters of common murres (COMU) and thick-billed murres (TBMU) breeding on St. George Island, Bering Sea.

\begin{tabular}{lrrrrrll}
\hline Species & $\begin{array}{r}\text { No. of } \\
\text { birds }\end{array}$ & $\begin{array}{c}\text { No. of } \\
\text { trips }\end{array}$ & $\begin{array}{r}\text { No. of } \\
\text { dive bouts }\end{array}$ & $\begin{array}{l}\text { No. of dive } \\
\text { bouts per trip }\end{array}$ & Trip & $\begin{array}{c}\text { Duration (h) } \\
\text { Total flight }\end{array}$ & Dive bouts \\
\hline COMU & 7 & 14 & 64 & $4.57 \pm 2.71$ & $13.21 \pm 4.79$ & $1.56 \pm 0.77$ & $1.79 \pm 3.74$ \\
TBMU & 12 & 21 & 79 & $3.76 \pm 2.86$ & $10.45 \pm 7.09$ & $1.40 \pm 0.80$ & $1.87 \pm 3.42$ \\
One-way ANOVA, & & & & $F_{1,33}=0.70$ & $F_{1,33}=1.62$ & $F_{1,33}=0.36$ & $F_{1,157}=0.02$ \\
$F$ and $P$ values & & & & $P=0.409$ & $P=0.212$ & $P=0.552$ & $P=0.892$ \\
\hline
\end{tabular}

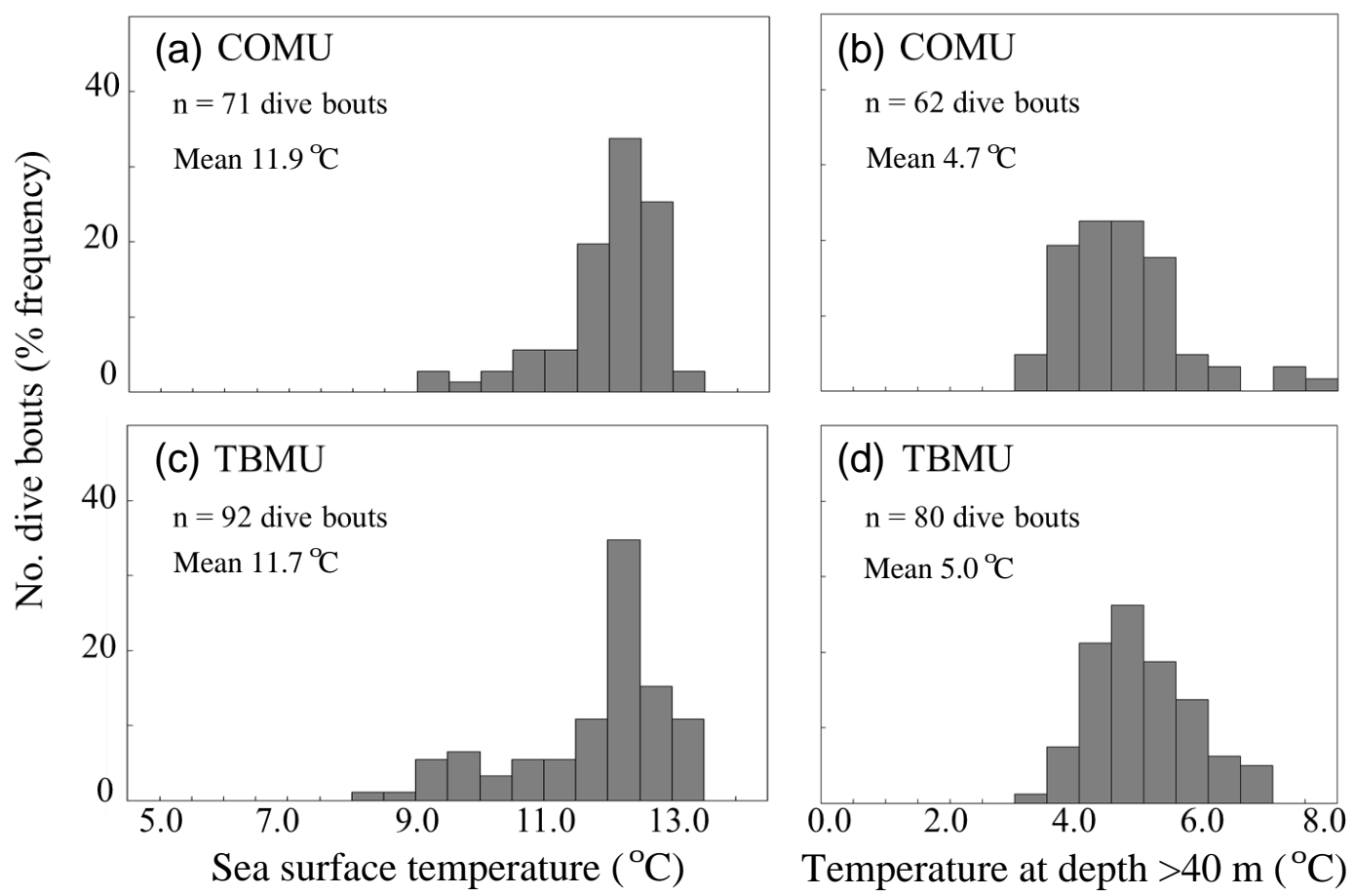

Figure 1. Frequency distribution of dive bouts in relation to (a) and (c) sea surface temperature (SST) and (b), (d) mean temperature at depth $(>40 \mathrm{~m})$ in the water column. Upper panels represent data for common murres (COMU) and lower panels represent data for thick-billed murres (TBMU).

for shallow dives, $11.1 \pm 8.5$ and $13.5 \pm 8.8 \%$ for deep dives, for COMUs and TBMUs respectively; GLM, $t=1.193$, $P=0.254$ ). There were no significant differences in the proportion of daytime and nighttime dives or shallow and deep dives between the sexes in either COMUs or TBMUs (GLM, $P>0.05)$.

During the daytime, the shallow diving depth $(<40 \mathrm{~m})$ did not differ between the species (Fig. 3c, d: $18.1 \pm 6.0 \mathrm{~m}$ for COMUs and $20.2 \pm 7.4 \mathrm{~m}$ for TBMUs; GLMM with LRT, $\left.\chi^{2}=0.30, P=0.581\right)$. However, the deep diving depth (> $40 \mathrm{~m}$ ) was deeper for COMUs $(74.2 \pm 8.7 \mathrm{~m})$ compared to TBMUs $(59.7 \pm 7.9 \mathrm{~m}$ : Fig. $3 \mathrm{c}$, d: GLMM with LRT, $\left.\chi^{2}=7.04, P=0.008\right)$. In the nighttime, the depth of shallow dives $(<40 \mathrm{~m})$ did not differ between the species (Fig. $3 \mathrm{~g}$, h: $15.4 \pm 4.0 \mathrm{~m}$ for COMUs and $19.1 \pm 6.2 \mathrm{~m}$ for TBMUs; GLMM with LRT, $\chi^{2}=1.12, P=0.289$ ). There were no significant differences between the sexes in either COMU or TBMU dive depths (GLMM with LRT, $P>0.05$ ).

The number of wing strokes during the bottom phase of day and night dives was higher in COMUs than in TBMUs (daytime, Fig. 3e, f: $1.95 \pm 0.16 \mathrm{~s}^{-1}$ for COMUs and $1.68 \pm 0.20 \mathrm{~s}^{-1}$ for TBMUs; GLMM with LRT, $\chi^{2}=5.978$, $P=0.014$ - nighttime, Fig. 3i, j: $1.84 \pm 0.07 \mathrm{~s}^{-1}$ for COMUs and $1.57 \pm 0.21 \mathrm{~s}^{-1}$ for TBMUs; GLMM with LRT, $\left.\chi^{2}=6.545, P=0.011\right)$. The number of wing strokes during the bottom phase of the dive was slightly higher during the daytime for both COMUs (GLMM with LRT, $\chi^{2}=8.551, P=0.003$ ) and TBMUs (GLMM with LRT, $\left.\chi^{2}=20.052, P<0.001\right)$. The number of wing strokes during the dive descent phase did not differ between the species either in the daytime $\left(2.29 \pm 0.07 \mathrm{~s}^{-1}\right.$ for COMUs and $2.18 \pm 0.21 \mathrm{~s}^{-1}$ for TBMUs: GLMM with LRT, $\left.\chi^{2}=3.301, P=0.069\right)$ or the nighttime $\left(2.23 \pm 0.11 \mathrm{~s}^{-1}\right.$ for 


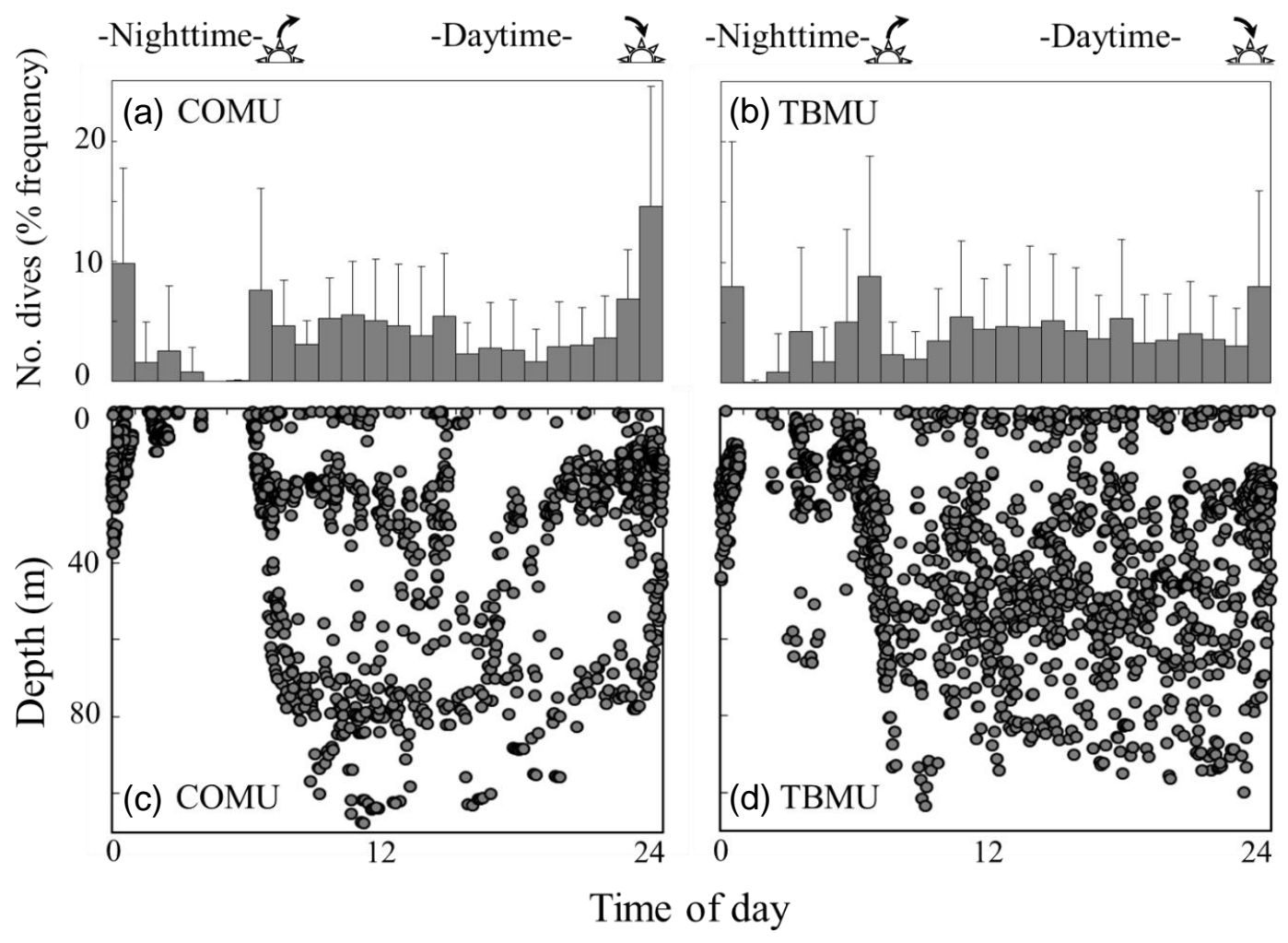

Figure 2. (a, c) Frequency distribution and $(\mathbf{b}, \mathbf{d})$ depth distribution pattern of dives in relation to time of day. Left panels represent data for common murres (COMU) and right panels represent data for thick-billed murres (TBMU). Means \pm standard deviation (SD) are shown in (b) and (d), calculated by individual bird data. The timing of sunrise and sunset is shown by marks on the top horizontal axis.

COMUs and $2.19 \pm 0.16 \mathrm{~s}^{-1}$ for TBMUs: GLMM with LRT, $\left.\chi^{2}=1.387, P=0.239\right)$. There were no significant differences between the sexes in the number of wing strokes in either species (GLMM with LRT, $P>0.05$ ).

\subsection{Diet}

We observed 20 and 39 prey items delivered by parent COMUs and TBMUs, respectively, to feed their chicks. The proportion of fishes (consisting of 6 walleye pollock (Gadus chalcogrammus), 1 sculpin (Cottoidae), 1 flatfish (Pleuronectidae) and 9 unidentified fish for COMUs, and 9 walleye pollock, 2 sculpins, 1 prickleback (Stichaeidae) and 10 unidentified fish for TBMUs) was higher for COMUs compared to TBMUs ( $\chi^{2}$ test, $\chi^{2}=6.108, P=0.047$ ). Conversely, the proportion of invertebrates (consisting of 1 squid (Gonatidae) for COMUs, 12 squids and 1 unidentified crustacean for TBMUs) was higher for TBMUs compared to COMUs.

The stable isotope analysis for red blood cells showed differences in the potential adult diet between the species. $\delta^{15} \mathrm{~N}$ was higher in COMUs than in TBMUs (Fig. 4: $14.5 \pm 0.3 \%$ for COMUs and $13.1 \pm 0.4 \%$ or tor TBMUs; one-way ANOVA, $\left.F_{1,30}=134.84, P<0.001\right) . \delta^{13} \mathrm{C}$ was also slightly higher for COMUs compared to TBMUs (Fig. 4:
$-19.4 \pm 0.2 \%$ for COMUs and $-19.8 \pm 0.2 \%$ o for TBMUs; one-way ANOVA, $F_{1,30}=37.71, P<0.001$ ). There were no significant differences among the sexes in $\mathrm{CO}$ MUs stable isotope data (one-way ANOVA, $P>0.05$ ). Because of an inequality in number of male and females $(n=2$ males and 16 females) in TBMUs, the effect of sex could not be analyzed, but males generally showed higher $\delta^{15} \mathrm{~N}$ value ( $13.7 \%$ o for both males) compared to those of females (13.1 $\pm 0.3 \%$ o, ranging 12.4 to $13.8 \%$ ), while $\delta^{13} \mathrm{C}$ values of males $(-19.7$ and $-19.8 \%$ ) were similar to those of females $(-19.8 \pm 0.2 \%$ o, ranging -20.0 to $-19.4 \%$ ) .

Based on the Bayesian mixing analysis for estimating potential food sources, COMUs were inferred to have fed on more fishes such as age- 1 walleye pollock and age-0 flounder, whereas TBMUs were inferred to have fed on more invertebrates such as euphausiids and squids (Figs. 6 and 7).

\subsection{Stress hormone}

The baseline CORT did not differ between the species (log-transformed mean $=0.43 \pm 0.25 \mathrm{ng} \mathrm{mL}^{-1}$ for COMUs and $0.37 \pm 0.27 \mathrm{ng} \mathrm{mL}^{-1}$ for TBMUs; one-way ANOVA, $\left.F_{1,31}=0.35, P=0.559\right)$. There was no significant difference between the sexes in COMUs baseline CORT (one-way ANOVA, $P>0.05$ ). Baseline CORT of males 

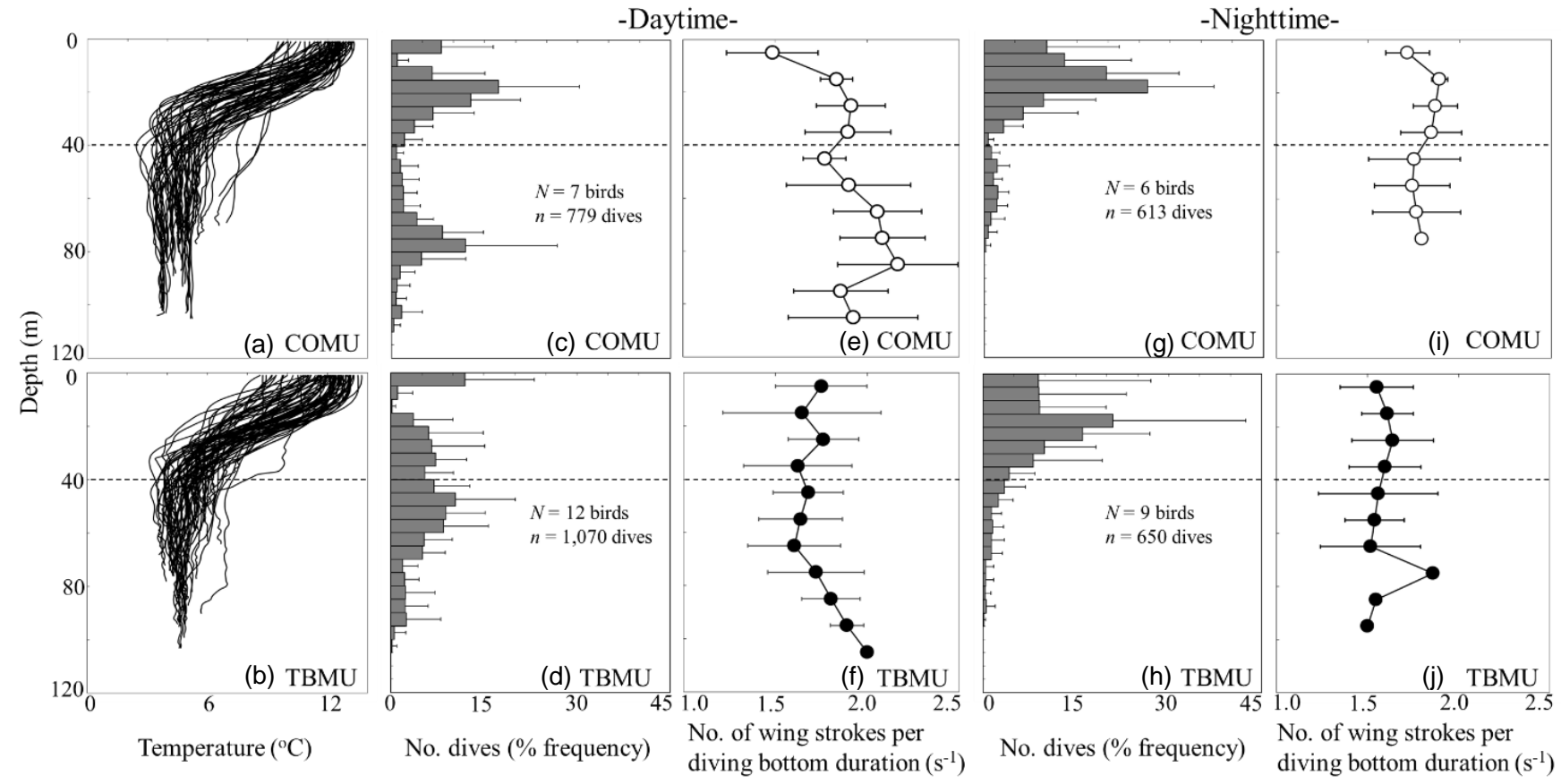

Figure 3. (a, b) Vertical temperature profiles where foraging dive occurred with (c, $\mathbf{d}, \mathbf{g}, \mathbf{h})$ frequency distribution of dives and (e, f, i, j) number of wing strokes per diving bottom phase, in relation to dive depth. Upper panels represent data for common murres (COMU) and lower panels represent data for thick-billed murres (TBMU). Panels (c), (d), (e), and (f) represent data for the daytime, and panels (g) to (j) represent data for the nighttime. Means \pm standard deviation (SD) are shown, except for (a) and (b), which are calculated from individual bird data. Sample number of birds $(N)$ and dives $(n)$ are shown in (c) to (h).

(a) COMU $n=20$ observations

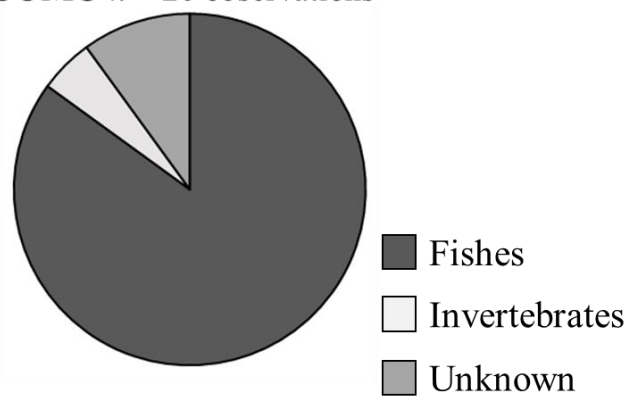

(b) TBMU $n=39$ observations

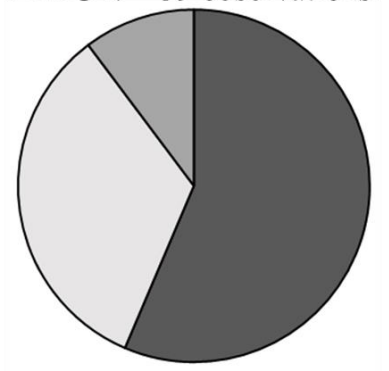

Figure 4. Diet composition of (a) common murres (COMU) and (b) thick-billed murres (TBMU) based on direct observations of prey delivered to nests. (log-transformed mean $=0.17 \pm 0.31 \mathrm{ng} \mathrm{mL}^{-1}$ ) was slightly lower than that of females $\left(0.44 \pm 0.23 \mathrm{ng} \mathrm{mL}^{-1}\right)$ in TBMUs (one-way ANOVA, $F_{1,20}=4.92, P=0.038$ ).

\section{Discussion}

This study investigated the fine-scale differences in foraging behavior between two closely related seabirds: common and thick-billed murres. Both species showed similar foraging ranges and diel patterns of diving (Table 1, Fig. 2). Both species used similar thermal environments at sea, with no significant interspecific differences in SST, temperature at depth, thermocline depth and intensity (Fig. 1). Thus the two species appeared to forage in similar stratified water masses, presumably in the middle- or outer-shelf domains around St. George Island (Kinder et al., 1983; Takahashi et al., 2008). However, despite similarities in geographic location, COMUs dove to deeper depths in the daytime and showed more frequent underwater wing strokes during dive bottom time, compared to TBMUs (Fig. 3). In addition, COMUs used higher-trophic-level prey, presumably consisting of larger fishes such as age-1 walleye pollock, as estimated from SIAR models, whereas TBMUs used lowertrophic-level prey, which possibly includes squids and mesozooplankton (Figs. 4, 5, 6 and 7). Red blood cells reflect adult diet during incubation and early chick rearing (half-life 


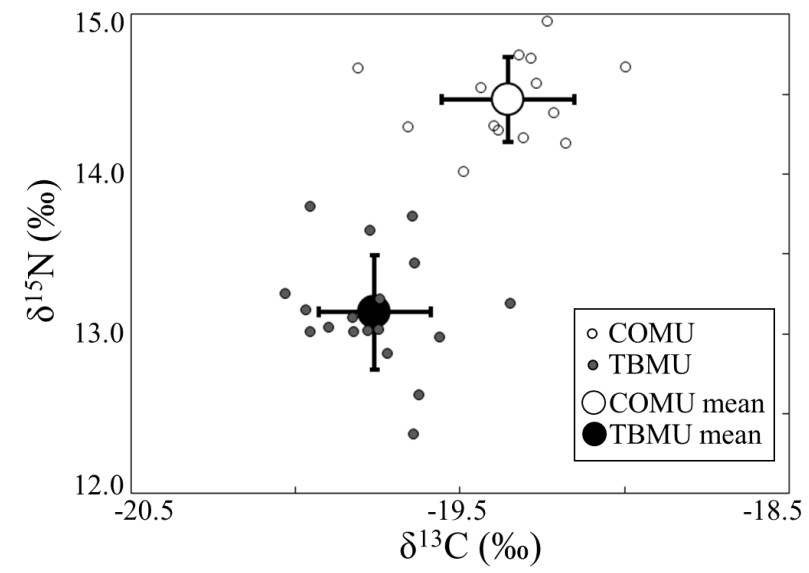

Figure 5. Carbon $\left(\delta^{13} \mathrm{C}\right)$ and nitrogen $\left(\delta^{15} \mathrm{~N}\right)$ stable isotopic ratio values of common murres (COMU: open circles) and thick-billed murres (TBMU: closed circles) measured in red blood cells. Smaller circles show individual data, and larger circles with error bars show means \pm standard deviation (SD).

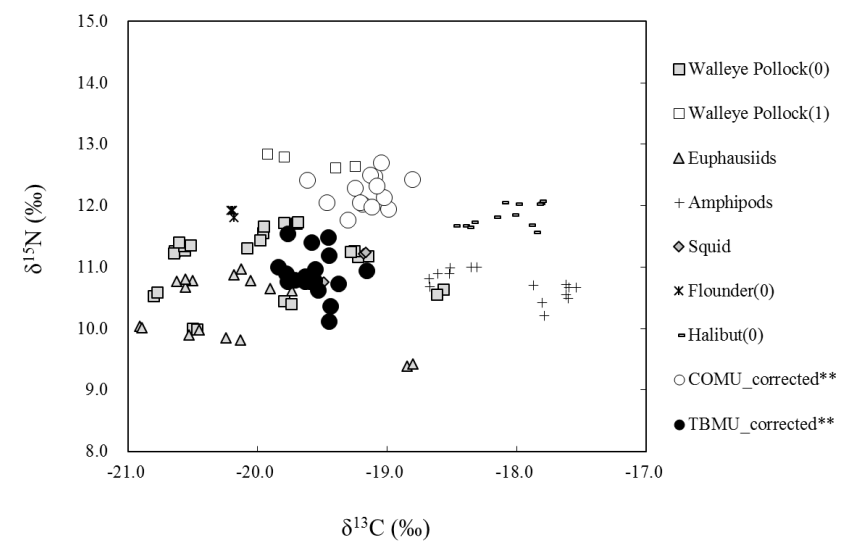

Figure 6. Carbon $\left(\delta^{13} \mathrm{C}\right)$ and nitrogen $\left(\delta^{15} \mathrm{~N}\right)$ stable isotopic ratio values of potential food samples caught around the vicinity of the study colony. Different symbols represent each potential food item. ** The enrichment factors $-0.19 \%$ ofor $\delta^{13} \mathrm{C}$ and $2.25 \%$ for $\delta^{15} \mathrm{~N}$ were preliminarily applied to the bird data (open circles for common murres and closed circles for thick-billed murres). Note that the potential food samples were collected in 2009 , as no data were available in 2014 .

4 weeks: Barger et al., 2016; Hobson and Clark, 1993). A recent study suggested that, under good foraging conditions, the dietary differences between sympatrically breeding COMUs and TBMUs becomes greater during the chickrearing period compared to the incubation or pre-laying period (Barger et al., 2016). Therefore, it is likely that in this study the differences in the trophic levels between chickrearing COMUs and TBMUs were even greater than suggested from our results based on stable isotope analysis of red blood cells.

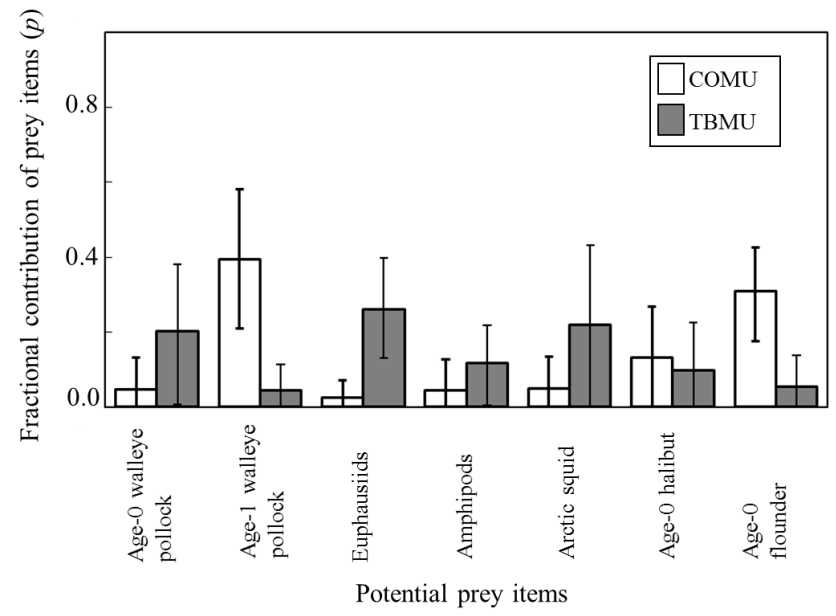

Figure 7. Diet compositions of common (COMU: open boxes) and thick-billed murres (TBMU: closed boxes) as estimated by Bayesian Mixing Analysis of stable isotope values of birds (red blood cells) and those of their potential prey items (whole body tissues). Means $\pm 95 \%$ credible intervals of the fractional contribution $(p)$ of seven different prey items are shown. Note that the potential food samples were collected in 2009.

Several studies have shown horizontal segregation of foraging habitat between sympatric, closely related, diving seabirds (e.g., Lynnes et al., 2002; Barger et al., 2016), whereas few studies have reported vertical segregation in spatially overlapped foraging areas (but see Mori and Boyd, 2004). Mori and Boyd (2004) found that smaller macaroni penguins dove to shallower depths than larger gentoo penguins, and suggested that differences in diving capacity based on body mass contributed to the observed vertical segregation. The effect of body mass on vertical segregation is not clear in our study, because the smaller COMUs dove to deeper depths below the thermocline $(>40 \mathrm{~m})$ in the daytime than the larger TBMUs (Fig. 3). Contrary to the expected relatively poor diving capacity of COMUs compared to TBMUs, COMUs foraged at deeper depths in the daytime probably to capture larger fishes.

Larger fast-swimming fishes, including age-1 walleye pollock, are distributed at deeper depths in the daytime compared to smaller age- 0 pollock, and migrate up to thermocline depths at night (Lang et al., 2000; Schabetsberger et al., 2000; Hurst, 2007). Diving seabirds are considered to feed mostly during the diving bottom phase (Elliott et al., 2008). Accordingly, we observed the deeper diving depths in the daytime and more frequent wing strokes during the bottom phase of COMU dives. Combined with higher trophic levels of their prey, these data suggest that COMUs tended to forage on more mobile prey such as large fishes, compared to TBMUs. There are several possible factors affecting the interspecific differences/similarities in foraging behavior between closely related COMUs and TBMUs, such as (1) physiology 
and morphology, (2) breeding stages and nest attendance, and (3) prey availability.

Croll and McLaren (1993) suggested that resting or diving metabolic rates are expected to be similar between $\mathrm{CO}$ MUs and TBMUs. On the other hand, TBMUs at our study colony had larger body mass, larger wing area and smaller wing loading than COMUs. According to previous studies (Thaxter et al., 2010; Linnebjerg et al., 2013), alcid species with larger body mass are expected to dive deeper, and those with smaller wing loading are expected to fly farther. However, these predictions were not supported in our study. A morphological study pointed out that the smaller wings of COMUs enable them to swim more agilely than TBMUs (Spring, 1971). COMUs' more frequent wing strokes during the dive bottom phase (Fig. 3e, f, i, j) are possibly due to pursuing larger fishes, and may support the observation by Spring (1971) that their small wing size enables them to chase down large, fast-moving juvenile fish.

This study was conducted during the chick-rearing period of both species, when the energy demands of parents are highest (Ricklefs, 1983). High energy demands may force both COMUs and TBMUs to forage closer to the colony, compared to during incubation (Barger et al., 2016) and postor pre-breeding periods (Linnebjerg et al., 2013). In addition, one member of a pair of COMUs consistently guarded their chicks like during incubation on the narrow open ledges at the study colony. This aspect was different from COMUs at other locations where nests are more protected, and parents can leave their chicks alone and spend more time foraging (Linnebjerg et al., 2015). Potential foraging range and the diel patterns of diving were similar between COMUs and TBMUs at the study colony (Table 1, Fig. 2), which may reflect the necessity to guard chicks, along with the similar nest attendance patterns.

There are few available data on local food availability during the study period. In terms of nutritional stress, both COMUs and TBMUs showed lower concentrations of stress hormone in the study year, compared to those reported in other years on St. George Island (Harding et al., 2013; Paredes et al., 2015) and elsewhere (Barger and Kitaysky, 2012), suggesting that the food conditions of the study year were favorable for both species (Kitaysky et al., 2007, 2010; Barrett et al., 2015). In addition, the abundance of age- 0 pollock in the eastern Bering Sea (in the $150 \mathrm{~km}$ radius around Pribilof Islands) measured within the upper $15 \mathrm{~m}$ of the water column was high in 2014 compared to other years since 2003 (W. Strasburger, Ted Stevens Marine Research Institute Juneau, Alaska, personal communication, 2015). Although seabirds breeding on St. George Island may be prone to experience food shortage due to high bird density (Hunt Jr. et al., 1986), murres were not food-limited during the study period, and the interspecific foraging niche partitioning occurred under favorable foraging conditions. Barger et al. (2016) suggested that the resource partitioning proactively increases during this period of elevated energetic needs without appar- ent food limitations. Our study provides further support that chick-rearing COMUs and TBMUs breeding on St. George Island proactively partition resources when food conditions are relatively good.

Overall, at the study colony, chick-rearing COMUs and TBMUs foraged in similar foraging ranges with a similar diel pattern of diving frequency. Intersexual foraging differences were not clear compared to other colonies (see Paredes et al., 2008; Linnebjerg et al., 2015). Segregation in prey species with different vertical distribution and mobility may allow the use of similar foraging ranges of these closely related species, and may possibly reflect interspecific morphological differences. Other studies have found prey segregation in other regions; however, horizontal and/or vertical foraging segregation have also been reported between chick-rearing COMUs and TBMUs (e.g., Barger et al., 2016). Barger et al. (2016) reported chick-rearing COMUs and TBMUs used different foraging habitats, as reflected in travel distances to foraging areas and SST distributions of their foraging dives. TBMUs performed shorter foraging trips, deeper dives and fed their chicks squid, while COMUs foraged farther from the colony, performed shallower dives, and delivered fish to feed their chicks. Such a spatial segregation by distance was not observed in our study (Table 1). TBMU populations exhibit various behavioral patterns, which may be due to interregional differences in morphology (Paredes et al., 2015). TBMUs from St. Paul Island with larger body mass and wing loading performed shorter foraging trips and deeper dives, whereas TBMUs from St. George Island with smaller body mass and wing loading performed longer foraging trips and shallower dives (Orben et al., 2015; Paredes et al., 2015). Thus, segregation patterns between COMUs and TBMUs may differ among regions partly because their morphology differs at a regional scale.

It has been reported that, in other regions, COMUs prefer larger, more mobile fish, including walleye pollock and capelin (Mallotus villosus), whereas TBMUs use more various prey, including benthic fishes, cephalopods and mesozooplankton (Hunt Jr. et al. 1981a; Barrett et al., 1997; Bryant et al., 1998; Barger et al., 2016). Spring (1971) and Ogi (1979) suggested that COMUs' more slender bill and palate, along with their corneous tongue, reflect their more piscivorous tendencies, whereas the wider bill and palate and the less corneous tongue of the TBMUs reflect their invertebrate feeding habits. In the Bering Sea, the recruitment of age-1 walleye pollock remained high during cold regimes, whereas it fell during warm regimes (Ianelli et al., 2009; Coyle et al., 2011). During warm regimes, distribution of age- 0 walleye pollock shifts northwards, their abundance increases over the southeastern Bering Sea shelf and their lipid content decreases (Wyllie-Echeverria and Wooster, 1998; Hunt Jr. et al., 2011). A recent study suggests that breeding success of TBMUs was higher in years when parents fed more on on-shelf fish species including walleye pollock, rather than oceanic fish (myctophids) or invertebrates 
(Renner et al., 2014). Reproductive success was similar between the species at the study colony in 2014 (0.61 for COMUs and 0.55 for TBMUs) and it was higher than long-term averages (Mudge et al., 2015). This is supported by the relatively low level of stress hormones measured in our study birds, which suggests that the behavioral data shown in this study represent a year with favorable feeding conditions for both COMUs and TBMUs. In order for a clear prediction to be made regarding how these two species will respond to environmental change it would be necessary to determine whether the segregation patterns observed in this study persist in years with relatively unfavorable foraging conditions.

In conclusion, interspecific comparison of foraging behavior between closely related common and thick-billed murres in the Bering Sea showed that both species foraged in similar foraging ranges with a similar diel pattern of diving frequency. However, common murres dove to deeper depths below the thermocline $(>40 \mathrm{~m})$ in the daytime, showed more frequent underwater wing strokes during the bottom phase of dives, and used higher-trophic-level prey, compared to thickbilled murres. Common murres have smaller wings, which potentially enable the pursuit of more mobile prey. These results suggest that common and thick-billed murres segregated prey species in relation to differences in their morphology. These differences in food resource use may lead to the differential responses of the two murre species to marine environmental changes in the Bering Sea.

Author contributions. Nobuo Kokubun, Akinori Takahashi, Alexander S. Kitaysky and Yutaka Watanuki designed and coordinated the research project. Nobuo Kokubun, Takashi Yamamoto and Nobuhiko Sato conducted the field study on St. George Island, Alaska. Alexis Will and Alexander S. Kitaysky performed stable isotope and stress hormone analyses in the laboratory. Nobuo Kokubun, Takashi Yamamoto and Nobuhiko Sato analyzed the behavioral data. Nobuo Kokubun wrote the manuscript with contributions from all of the co-authors.

Acknowledgements. We would like to thank Marc Romano and the staff of the US Fish and Wildlife Service for logistical support during fieldwork. The St. George Traditional Council and St. George Island Institute also provided logistical support to the field team. We are grateful to George L. Hunt Jr. and David G. Ainley for providing helpful comments and suggestions for revising the original manuscript. This study was funded by the Green Network of Excellence Program (GRENE) Arctic Climate Change Research Project: "Rapid Change of the Arctic Climate System and its Global Influences". The production of this paper was supported by an NIPR publication subsidy. This study was conducted under all required federal, state, and special use permits, and in accordance with the University of Alaska Fairbanks IACUC (assurance \# 471022-2). All live-capture and tagging works were conducted following the Federal Fish and Wildlife Permit issued by the US Fish and Wildlife Service (permit \# MB70337A-3) and the Scientific Permit issued by the State of Alaska (permit \# 14-109).
Edited by: T. Hirawake

\section{References}

Barger, C. P. and Kitaysky, A. S.: Isotopic segregation between sympatric seabird species increases with nutritional stress, Biol. Lett., 8, 442-445, 2012.

Barger, C. P., Young, R. C., Cable, J. M., Ito, M., and Kitaysky, A. S.: Resource partitioning between sympatric seabird species increases during chick-rearing, Ecosphere, in press, 2016.

Barrett, R. T., Asheim, M., and Bakken, V.: Ecological relationships between two sympatric congeneric species, common murres and thick-billed murres, Uria aalge and $U$. lomvia, breeding in the Barents Sea, Can. J. Zoolog., 75, 618-631, 1997.

Barrett, R. T., Erikstad, K. E., Sandvik, H., Myksvoll, M., JenniEierlmann, S., Kristensen, D. L., Moum, T., Reiertsen, T. K., and Vikeb $\varnothing$, F.: The stress hormone corticosterone in a marine top predator reflects short-term changes in food availability, Ecol. Evol., 5, 1306-1317, 2015.

Benowitz-Fredericks, Z. M., Shultz, M. T., and Kitaysky, A. S.: Stress hormones suggest opposite trends of food availability for planktivorous and piscivorous seabirds in 2 years, Deep-Sea Res. Pt. II, 55, 1868-1876, 2008.

Bryant, R., Jones, I. L., and Hipfner, J. M.: Responses to changes in prey availability by common murres and thick-billed murres at the Gannet Islands, Labrador, Can. J. Zoolog., 77, 1278-1287, 1998.

Clavel, J., Julliard, R., and Devictor, V.: Worldwide decline of specialist species: toward a global functional homogenization?, Front. Ecol. Environ., 9, 222-228, 2011.

Coachman, L. K.: Circulation, water masses and fluxes on the southeastern Bering Sea Shelf, Cont. Shelf Res., 5, 23-108, 1986.

Croll, D. A. and McLaren, E.: Diving metabolism and thermoregulation in common and thick-billed murres, Comp. Physiol., 163, 160-166, 1993.

Croxall, J. P., Prince, P. A., and Reid, K.: Dietary segregation of krill-eating South Georgia seabirds, J. Zool., 242, 531-556, 1997.

Coyle, K. O., Eisner, L. B., Mueter, F. J., Pinchuk, A. I., Janout, M. A., Cieciel, K. D., Farley, E. V., and Andrews, A. G.: Climate change in the southeastern Bering Sea: impacts on pollock stocks and implications for the oscillating control hypothesis, Fish. Oceanogr., 20, 139-156, 2011.

Daunt, F., Peters, G., Scott, B., Gremillet, D., and Wanless, S.: Rapid-response recorders reveal interplay between marine physics and seabird behaviour, Mar. Ecol.-Prog. Ser., 255, 283 288, 2003.

Dragoo, D. E., Renner, H. M., and Irons, D. B.: Breeding status and population trends of seabirds in Alaska, 2014, US Fish and Wildlife Service Report AMNWR 2015/03, Homer, Alaska, 2015.

Elliott, K. H., Woo, K., Gaston, A. J., Benvenuti, S., Dall'Antonia, L., and Davoren, G. K.: Seabird foraging behaviour indicates prey type, Mar. Ecol.-Prog. Ser., 233, 89-103, 2008.

Elliott, K. H., Gaston, A. J., and Crump, D.: Sex-specific behavior by a monomorphic seabird represents risk partitioning, Behav. Ecol., 21, 1024-1032, 2010. 
Falk, K., Benvenuti, S., Dall'Antonia, L., Kampp, K., and Ribolini, A.: Time allocation and foraging behaviour of chick rearing Brünnich's guillemots Uria lomvia in high-arctic Greenland, Ibis, 143, 82-92, 2000.

Gallagher, A. J., Hammerschlag, N., Cooke, S. J., Costa, D. P., and Irschick, D. J.: Evolutionary theory as a tool for predicting extinction risk, Trends Ecol. Evol., 30, 61-65, 2015.

Gaston, A. J. and Jones, I. L.: The Auks: Alcidae, Oxford University Press, Oxford, London, 1998.

Griffiths, R., Double, M. C., Orr, K., and Dawson, R. J. G.: A DNA test to sex most birds, Mol. Ecol., 7, 1071-1075, 1998.

Harding, A., Paredes, R., Suryan, R., Roby, D., Irons, D., Orben, R., Renner, H., Young, R., Barger, C., Dorresteijn, I., and Kitaysky, A.: Does location really matter? An inter-colony comparison of seabirds breeding at varying distances from productive oceanographic features in the Bering Sea, Deep-Sea Res. Pt. II, 94, 178$191,2013$.

Hobson, K. A. and Clark, R. G.: Turnover of ${ }^{13} \mathrm{C}$ in cellular and plasma fractions of blood: implications for nondestructive sampling in avian dietary studies, Auk, 110, 638-641, 1993.

Hobson, K. A., Fisk, A., Karnovsky, N., Holst, M., Gagnon, J.-M., and Fortier, M.: A stable isotope $\left(\delta^{13} \mathrm{C}, \delta^{15} \mathrm{~N}\right)$ model for the North Water food web: implications for evaluating trophodynamics and the flow of energy and contaminants, Deep-Sea Res. Pt. II, 49, 5131-5150, 2002.

Hunt Jr., G. L., Burgeson, B., and Sanger, G. A.: Feeding ecology of seabirds of the eastern Bering Sea, in: The Eastern Bering Sea shelf: oceanography and resources, edited by: Hood, D. and Calder, J. A., Juneau, AK: Office of Marine Pollution Assessment, National Oceanographic and Atmospheric Administration, 629-648, 1981a.

Hunt Jr., G. L., Eppley, Z., and Drury, W. H.: Breeding distribution and reproductive biology of marine birds in the eastern Bering Sea, in: The Eastern Bering Sea shelf: oceanography and resources, edited by: Hood, D. and Calder, J. A., Juneau, AK: Office of Marine Pollution Assessment, National Oceanographic and Atmospheric Administration, 649-687, 1981b.

Hunt Jr., G. L., Eppley, Z. A., and Schneider, D. C.: Reproductive performance of seabirds: the importance of population and colony size, Auk, 103, 306-317, 1986.

Hunt Jr., G. L., Coyle, K. O., Eisner, L. B., Farley, E. V., Heintz, R., A., Mueter, F., Napp, J. M., Overland, J. E., Ressler, P. H., Salo, S., and Stabeno. J.: Climate impacts on eastern Bering Sea foodwebs: a synthesis of new data and an assessment of the Oscillating Control Hypothesis, ICES J. Mar. Sci., 68, 1230-1243, 2011

Hurst, T. P.: Thermal effects on behavior of juvenile walleye pollock (Theragra chalcogramma): implications for energetics and food web models, Can. J. Fish. Aquat. Sci., 64, 449-457, 2007.

Ianelli, J. N., Barbeaux, S., Honkalehto, T., Kotwicki, S., Aydin, K., and Williamson, N.: Assessment of the walleye pollock stock in the Eastern Bering Sea, in: Stock Assessment and Fishery Evaluation Report of the Groundfish Resources of the Bering Sea/Aleutian Islands Regions. Anchorage: North Pacific Fisheries Management Council, section 1, 49-148, 2009.

Irons, D. B., Anker-Nilssen, T., Gaston, A. J., Byrd, G. V., Falk, K., Gilchrist, G., Hario, M., Hjernquist, M., Krasnov, Y. V., Mosvech, A., Olsen, B., Peterson, A., Reid, J. B., Robertson, G. J., Strøm, H., and Wohl, K. D.: Fluctuations in circumpolar seabird populations linked to climate oscillations, Glob. Change Biol., 14, 1455-1463, 2008.

Jones, I. L., Rowe, S., Carr, S. M., Frazer, G., and Taylor, P.: Different patterns of parental effort during chick-rearing by female and male thick-billed murres (Uria lomvia) at a low-arctic colony, Auk, 119, 1064-1074, 2002.

Jones, N. M., Hoover, B. A., Heppel, S. A., and Kuletz, K.: A crossshelf gradient in $\delta^{15} \mathrm{~N}$ stable isotope values of krill and pollock indicates seabird foraging patterns in the Bering Sea, Deep-Sea Res. Pt. II, 109, 241-250, 2014.

Kinder, T. H., Hunt Jr., G. L., Schneider, D., and Schumacher, J. D.: Correlations between seabirds and oceanic fronts around the Pribilof Islands, Alaska, Estuar. Coast. Shelf S., 16, 309-319, 1983.

Kitaysky, A. S. and Golubova, E. G.: Climate change causes contrasting trends in reproductive performance of planktivorous and piscivorous alcids, J. Anim. Ecol., 69, 248-262, 2000.

Kitaysky, A. S., Piatt. J. F., and Wingfield, J. C.: Stress hormones link food availability and population processes in seabirds, Mar. Ecol.-Prog. Ser., 352, 245-258, 2007.

Kitaysky, A. S., Piatt, J. F., Hatch, S. A., Kitaiskaiya, E. V., Benowitz-Frederics, Z. M., Shultz, M. T., and Wingfield, J. C.: Food availability and population processes: severity of nutritional stress during reproduction predicts survival of long-lived seabirds, Func. Ecol., 24, 625-637, 2010.

Kokubun, N., Takahashi, A., Mori, Y., Watanabe, S., and Shin, H.C.: Comparison of diving behavior and habitat use between chinstrap and gentoo penguins breeding in the South Shetland Islands, Antarctica, Mar. Biol., 157, 811-825, 2010a.

Kokubun, N., Takahashi, A., Ito, M., Matsumoto, K., Kitaysky, A. S., and Watanuki, Y.: Annual variation in the foraging behaviour of thick-billed murres in relation to upper-ocean thermal structure around St. George Island, Bering Sea, Aquat. Biol., 8, 289 298, 2010b.

Lang, G. M., Brodeur, R. D., Napp, J., M., and Schabetsberger, R.: Variation in groundfish predation on juvenile walleye Pollock relative to hydrographic structure near the Pribilof Islands, Alaska, ICES J. Mar. Sci., 57, 265-271, 2000.

Linnebjerg, J. F., Guilford, T., Reuleaux, A., Mosbech, A., and Frediriksen, M.: Sympatric breeding auks shift between dietary and spatial resource partitioning across the annual cycle, Plos One, 8, e72987, doi:10.1371/journal.pone.0072987, 2013.

Linnebjerg, J. F., Reuleaux, A., Mouritsen, K. N., and Frederiksen, M.: Foraging ecology of three sympatric breeding alcids in a declining colony in southwest Greenland, Waterbirds, 38, 143-152, 2015.

Lynnes, A. S., Reid, K., Croxall, J. P., and Trathan, P. N.: Conflict or coexistence? Foraging distribution and competition for prey between Adélie and chinstrap penguins, Mar. Biol., 141, 11651174, 2002.

Masello, J. F., Hundry, R., Poisbleau, M., Demongin, L., Voigt, C. C., Wiekelski, M., and Quillfeldt, P.: Ecosphere Diving seabirds share foraging space and time within and among species, Ecosphere, 1, 1-28, 2010.

Mori, Y. and Boyd, I.: Segregation of foraging between two sympatric penguin species: does rate maximization make the difference?, Mar. Ecol.-Prog. Ser., 275, 241-249, 2004.

Mudge, M. L., Pietrzak, K. W., Drummond, B. A., and Romano, M. D.: Biological monitoring at St. George Island, Alaska, in 
2014, US Fish and Wildl. Serv. Rep., AMNWR 2015/02, Homer, Alaska, 2015.

Navarro, J., Votier, S. C., Aguzzi, J., Chiesa, J. J., Forero, M. G., and Phillips, R. A.: Ecological segregation in space, time and trophic niche of sympatric planktivorous petrels, Plos One, 8, e62897, doi:10.1371/journal.pone.0062897, 2013.

Niizuma, Y., Takahashi, A., Kuroki, M., and Watanuki, Y.: Sexing by external measurements of adult rhinoceros auklets breeding on Teuri island, Jpn. J. Ornithol., 48, 145-150, 1999.

Ogi, H.: Ecology of murres in subarctic Pacific regions, Aquabiology, 2, 19-26, 1979 (in Japanese with English abstract).

Orben, R. A., Paredes, R., Roby, D. D., Irons, D. D., and Shaffer, S. A.: Body size affects individual winter foraging strategies of thick-billed murres in the Bering Sea, J. Anim. Ecol., 84, 15891599, 2015.

Paredes, R., Jones, I. L., Boness, D. J., Trembley, Y., and Renner, M.: Sex-specific differences in diving behaviour of two sympatric Alcini species: thick-billed murres and razorbills, Can. J. Zoolog., 86, 610-622, 2008.

Paredes, R., Orben, R. A., Orben, Roby, D. D., Irons, D. B., Young, R., Renner, H., Tremblay, Y., Will, A., Harding, A. M. A., and Kitaysky, A. S.: Foraging ecology during nesting influences body size in a pursuit-diving seabird, Mar. Ecol.-Prog. Ser., 533, 261276,2015

Parnell, A. C., Inger, R., Bearhop, S., and Jackson, A. L.: Source partitioning using stable isotopes: coping with too much variation, PloS One, 5, e9672, doi:10.1371/journal.pone.0009672, 2010.

Pennycuick, C. J.: Modelling the flying bird, Academic Press, Amsterdam, 2008.

Pianka, E.: Competition and niche theory, in: Theoretical ecology: Principles and applications, edited by: May, R. M., Blackwell Scientific Publications, Oxford, London, 167-196, 1981.

R Development Core Team, R: A language and environment for statistical computing, Vienna: R Foundation for Statistical Computing, 2014.

Renner, H. M., Drummond, B. A., Benson, A.-M., and Paredes, R.: Reproductive success of kittiwakes and murres in sequential stages of the nesting period: Relationship with diet and oceanography, Deep-Sea Res. Pt. II, 109, 251-265, 2014.

Ricklefs, R. E.: Some considerations on the reproductive energetics of pelagic seabirds, Stud. Avian Biol.-Ser., 8, 84-94, 1983.

Schabetsberger, R., Brodeur, R. D., Cianelli, L., Napp, J. M., and Swartzman, G. L.: Diel vertical migration and interaction of zooplankton and juvenile walleye pollock (Theragra chalcogramma) at a frontal region near the Pribilof Islands, Bering Sea, ICES J. Mar. Sci., 57, 1283-1295, 2000.
Sowls, A. L., Hatch, S. A., and Lensink, C. J.: Catalog of Alaskan Seabird Colonies, US Fish and Wildlife Service, Washington, DC, 1978.

Spring, L.: A comparison of functional and morphological adaptations in the common murre (Uria aalge) and thick-billed murre (U. lomvia), Condor, 74, 1-27, 1971.

Squibb, R. C. and Hunt Jr., G. L.: A comparison of nesting-ledges used by seabirds on St. George Island, Ecology, 64, 727-734, 1983.

Takahashi, A., Matsumoto, K., Hunt Jr., G. L., Shultz, M. T., and Watanuki, Y.: Thick-billed murres use different diving behaviors in mixed and stratified waters, Deep-Sea Res. Pt. II, 55, 1837 1845, 2008.

Thaxter, C. B., Wanless, S., Daunt, F., Harris, M. P., Benvenuti, S., Watanuki, Y., Grémillet, D., and Hamer, K. C.: Influence of wing loading on the trade-off between pursuit-diving and flight in common guillemots and razorbills, J. Exp. Biol., 213, 10181025, 2010.

Trivelpiece, W. Z., Hinke, J. T., Miller, A. K., Reiss, C. S., Trivelpiece, S. Z., and Watters, G. M.: Variability in krill biomass links harvesting and climate warming to penguin population changes in Antarctica, P. Natl. Acad. Sci. USA, 108, 7625-7628, 2011.

Watanuki, Y., Mehlum, F., and Takakashi, A.: Water temperature sampling by Brunnich's guillemots with bird-borne data loggers, J. Avian Biol., 32, 189-193, 2001.

Watanuki, Y., Niizuma, Y., Gabrielsen, G. W., Sato, K., and Naito, Y.: Stroke and glide of wing-propelled divers: deep diving seabirds adjust surge frequency to buoyancy change with depth, P. R. Soc. Lond. B-Conta., 270, 483-388, 2003.

Watanuki, Y., Wanless, S., Harris, M., Lovvorn, J. R., Miyazaki, M., Tanaka, H., and Sato, K.: Swim speeds and stroke patterns in wing-propelled divers: a comparison among alcids and a penguin, J. Exp. Biol., 209, 1217-1230, 2006.

Wyllie-Echeverria, T. and Wooster, W. S.: Year-to-year variations in Bering Sea ice cover and some consequences for fish distribution, Fish. Oceanogr., 7, 159-170, 1998.

Yamamoto, T., Kokubun, N., Kikuchi, D. M., Sato, N., Takahashi, A., Will, A. P., Kitaysky, A. S., and Watanuki, Y.: Differential responses of seabirds to environmental variability over 2 years in the continental shelf and oceanic habitats of southeastern Bering Sea, Biogeosciences, 13, 2405-2414, doi:10.5194/bg-13-24052016, 2016. 